\title{
Validation of farm-scale methane emissions using nocturnal boundary layer budgets
}

\author{
J. Stieger ${ }^{1}$, I. Bamberger ${ }^{1,2}$, N. Buchmann ${ }^{1}$, and W. Eugster ${ }^{1}$ \\ ${ }^{1}$ ETH Zurich, Dept. of Environmental Systems Science, Institute of Agricultural Sciences, 8092 Zurich, Switzerland \\ ${ }^{2}$ Karlsruhe Institute of Technology (KIT), Institute of Meteorology and Climate Research, 82467 Garmisch-Partenkirchen, \\ Germany
}

Correspondence to: W. Eugster (eugsterw@ethz.ch)

Received: 24 June 2015 - Published in Atmos. Chem. Phys. Discuss.: 12 August 2015

Revised: 24 November 2015 - Accepted: 2 December 2015 - Published: 21 December 2015

\begin{abstract}
This study provides the first experimental validation of Swiss agricultural methane emission estimates at the farm scale. We measured $\mathrm{CH}_{4}$ concentrations at a Swiss farmstead during two intensive field campaigns in $\mathrm{Au}-$ gust 2011 and July 2012 to (1) quantify the source strength of livestock methane emissions using a tethered balloon system and (2) to validate inventory emission estimates via nocturnal boundary layer (NBL) budgets. Field measurements were performed at a distance of $150 \mathrm{~m}$ from the nearest farm buildings with a tethered balloon system in combination with gradient measurements at eight heights on a $10 \mathrm{~m}$ tower to better resolve the near-surface concentrations. Vertical profiles of air temperature, relative humidity, $\mathrm{CH}_{4}$ concentration, wind speed, and wind direction showed that the NBL was strongly influenced by local transport processes and by the valley wind system. Methane concentrations showed a pronounced time course, with highest concentrations in the second half of the night. NBL budget flux estimates were obtained via a time-space kriging approach. Main uncertainties of NBL budget flux estimates were associated with nonstationary atmospheric conditions and the estimate of the inversion height $z_{i}$ (top of volume integration). The mean NBL budget fluxes of $1.60 \pm 0.31 \mu \mathrm{g} \mathrm{CH}_{4} \mathrm{~m}^{-2} \mathrm{~s}^{-1}(1.40 \pm 0.50$ and $1.66 \pm 0.20 \mu \mathrm{g} \mathrm{CH}_{4} \mathrm{~m}^{-2} \mathrm{~s}^{-1}$ in 2011 and 2012 respectively) were in good agreement with local inventory estimates based on current livestock number and default emission factors, with $1.29 \pm 0.47$ and $1.74 \pm 0.63 \mu \mathrm{gCH}_{4} \mathrm{~m}^{-2} \mathrm{~s}^{-1}$ for 2011 and 2012 respectively. This indicates that emission factors used for the national inventory reports are adequate, and we conclude that the NBL budget approach is a useful tool to validate emission inventory estimates.
\end{abstract}

\section{Introduction}

Efforts to mitigate climate change via commitments to reduce national emissions require independent techniques to validate or at least constrain emission estimates reported by each nation. While anthropogenic $\mathrm{CO}_{2}$ emissions from fossil fuel combustion can be estimated quite accurately from the commercial census data used to determine national tax obligations, the emission rates of $\mathrm{CH}_{4}$ from non-fossil sources are much harder to determine. Here we aim at quantifying the farm-scale $\mathrm{CH}_{4}$ emissions from a farmstead in Switzerland in order to compare these flux estimates with best estimates used in the national inventory report (NIR) under the Kyoto protocol.

The governmental inventory estimates are based on standard procedures recommended by the IPCC (Lassey, 2008; Nisbet and Weiss, 2010; Heimann, 2011; Wang et al., 2011), e.g. national livestock numbers multiplied with default emission factors (EFs) derived from the IPCC guidelines and guidance (Penman et al., 2000). Despite considerable uncertainty of these default values, this estimation methodology has become commonly used in order to ensure conformity and comparability of reported greenhouse gas emissions among different nations (Lassey, 2007). Although an experimental validation of such inventory estimates by independent means would be highly beneficial to improve their overall credibility, the assessment of agricultural $\mathrm{CH}_{4}$ emissions by direct atmospheric measurements is still lacking also for Switzerland. Methane emissions in Switzerland are dominated by the agricultural sector ( $77.7 \%$ ), followed by emis- 
sions from waste treatment $(16.3 \%)$ and from the energy sector $(5.9 \%)$ (FOEN, 2015, data from year 2013).

Because of the high global warming potential of $\mathrm{CH}_{4}$ and due to its relatively short atmospheric residence time, already a small reduction of $\mathrm{CH}_{4}$ emissions will have a high impact on the global $\mathrm{CH}_{4}$ budget (Dlugokencky et al., 2011; Wang et al., 2011). However, in order to formulate feasible mitigation strategies, a deeper understanding and a precise quantification of emission variability and source strength are needed (Lowry et al., 2001; Ulyatt et al., 2002; Dengel et al., 2011).

Due to the lack of direct field experiments and poorly known EFs (Lowry et al., 2001; Lassey, 2007), the NIR estimates are associated with uncertainties of \pm 18.1 and $\pm 54.4 \%$ for enteric fermentation and manure management respectively (FOEN, 2015). Although recent studies conducted at the animal husbandry level in Switzerland (Staerfl et al., 2012; Zeitz et al., 2012) showed that using countryspecific EFs would not substantially alter the total estimate of livestock $\mathrm{CH}_{4}$ emissions, high uncertainty remains, as differing farming practices can have significant impacts on the EFs (Lowry et al., 2001; Saggar et al., 2004; Christie et al., 2012).

Several methods exist to quantify $\mathrm{CH}_{4}$ emissions from cattle, e.g. using $\mathrm{SF}_{6}$ tracer (e.g. Johnson et al., 1994; Deighton et al., 2014) to determine emissions per animal or via the release of an external $\mathrm{N}_{2} \mathrm{O}$ tracer (e.g. Griffith et al., 2008; IPCC , 2006) to determine the emissions of enteric fermentation from groups of animals. These tracer techniques have been useful for the quantification of known $\mathrm{CH}_{4}$ source components and especially of individual emissions per animal, requiring detailed knowledge of the transport pathways of tracers and the location of active $\mathrm{CH}_{4}$ sources. However, such methods tend to have some limitations as the scale of integration increases to a whole farmstead or even larger spatial scale. For the validation of an emission inventory that is supposed to cover the total of all known and unknown (or neglected) source components, mostly volume-integrated budget estimates are used, since such an approach has the potential to also reveal unexpected or unexpectedly large flux components of $\mathrm{CH}_{4}$.

These methods have been useful for the quantification of known $\mathrm{CH}_{4}$ source components but tend to have some limitations as the scale of integration increases to a whole farmstead or even larger spatial scales. Moreover, these tracer techniques require detailed knowledge of the transport pathways of tracers and the location of active $\mathrm{CH}_{4}$ sources with which they must be collocated to provide realistic flux estimates. However, for the validation of an emission inventory that is supposed to cover the total of all known and unknown (or neglected) source components, mostly volume-integrated budget estimates are used, since such an approach has the potential to also reveal unexpected or unexpectedly large flux components of $\mathrm{CH}_{4}$.

Aircraft campaigns measuring vertical $\mathrm{CH}_{4}$ profiles (Fowler et al., 1996; Denmead et al., 2000; Lassey et al.,
2000; Wratt et al., 2001) or horizontal $\mathrm{CH}_{4}$ transects (Hiller et al., 2014b) have successfully provided regional-scale $\left(\geq 10^{4} \mathrm{~km}^{2}\right.$ ) flux estimates. For groups of cattle at the field or paddock scale $\left(<0.5 \mathrm{~km}^{2}\right)$, tracer release (Griffith et al., 2008; Leytem et al., 2011), the integrated horizontal flux method (Laubach and Kelliher, 2004; Griffith et al., 2008), and the point-source dispersion modelling and measurement approach (McGinn et al., 2011; McGinn and Beauchemin, 2012) have demonstrated their usefulness. At the farm scale in-between $\left(\approx 0.5-5 \mathrm{~km}^{2}\right)$, McGinn et al. (2006) have used a combination of tracer release, line-averaged concentration measurements, and inverse modelling of fluxes.

Inventory estimates account for neither the large spatial heterogeneity nor the temporal variability of $\mathrm{CH}_{4}$ sources (Wang et al., 2011). While spatially explicit inventories improve the overall spatial representativeness of the NIR, their accuracy still remains unclear due to the lack of small-scale validation data. This underpins the need for detailed local to regional-scale measurements.

Little is known about the temporal variability and spatial heterogeneity of different $\mathrm{CH}_{4}$ sources, although an increasing number of studies show the importance of assessing $\mathrm{CH}_{4}$ budgets via atmospheric measurements (Fowler et al., 1996; Beswick et al., 1998; Ulyatt et al., 2002; Zinchenko et al., 2002; Pattey et al., 2006; Detto et al., 2010; Pendall et al., 2010; Harper et al., 2011; Baldocchi et al., 2012). So far, a fair number of studies estimated livestock $\mathrm{CH}_{4}$ emissions via atmospheric concentration measurements without the deployment of chambers (Judd et al., 1999; Denmead et al., 2000; Laubach and Kelliher, 2004, 2005a, b; Laubach et al., 2008; Grobler et al., 2014). Unfortunately, only a few studies compare their results to inventory estimates directly (Levin et al., 1999; Lowry et al., 2001; Hsu et al., 2010; Hiller et al., 2014b). Using different budgeting approaches (e.g. convective and nocturnal boundary layer (NBL) budgets, mass balance method), Denmead et al. (2000) found a good agreement of budget estimates with the respective inventory estimates.

Therefore, in this study, we focus on the farm scale, by (1) quantifying the $\mathrm{CH}_{4}$ source strength of a typical Swiss farmstead $\left(0.5-5 \mathrm{~km}^{2}\right)$ via NBL $\mathrm{CH}_{4}$ budget fluxes (average surface fluxes) using vertical $\mathrm{CH}_{4}$ concentration profiles within the atmospheric boundary layer (ABL). In addition, (2) we use experimentally derived NBL budget fluxes for inventory validation at different spatial resolutions, i.e. the NIR and the Swiss spatially explicit inventory (SEI) as well as a direct inventory estimate at the farm scale.

\section{Materials and methods}

\subsection{Site description}

We performed two intensive measurement campaigns during 16-17 August 2011 and 24-27 July 2012 at the ETH research 
station Chamau $\left(47^{\circ} 12^{\prime} 37^{\prime \prime} \mathrm{N}, 8^{\circ} 24^{\prime} 38^{\prime \prime} \mathrm{E}\right.$ at 393 ma.s.1.), which is located in the lower Reuss Valley in central Switzerland. The dominant land use category in the Reuss valley is agriculture (56.5\%; FSO, 2012), followed by forests $(22.5 \%)$. Of the station's total area (62.03 ha), $72.4 \%$ is covered by grassland used for grazing and forage production (Zeeman et al., 2010; Suter, 2011). Cropland used for silage maize production, forests, and farm infrastructure cover $11.07 \%, 8.28 \%$, and $8.25 \%$ respectively. The grasslands are intensively managed (cut and fertilized about 5 to 6 times a year; detailed management information for year 2012 is given by Merbold et al., 2014) and dominated by mixed ryegrass-clover vegetation (Gilgen and Buchmann, 2009). The measurement periods did not include management events (e.g. cutting or fertilization). With respect to $\mathrm{CH}_{4}$, the grasslands have shown negligible soil $\mathrm{CH}_{4}$ fluxes on a daily timescale while acting as a small sink on an annual timescale (Imer et al., 2013). Livestock populations at Chamau vary according to the seasonal three-stage farming system. In summer, most cattle are moved to higher altitudes, whereas swine, goats, and sheep stay stationary at the farm. During our measurement periods, cattle and swine were inside the barns, while goats and sheep were located outside at the meadows.

Local meteorology in the Reuss Valley is dominated by a prominent valley wind regime, where prevailing winds from the NNW towards the Alps during the day are replaced by cold air drainage flows from SSE during the night, promoting the development of a shallow nocturnal boundary layer. Information was available from an earlier project at a nearby location where meteorological tethered balloon soundings were carried out in the lowest $1500 \mathrm{~m}$ of the ABL (Messerli, 1992; Utiger, 1992). These pilot studies showed that the stable nocturnal boundary layer is rather shallow and restricted to the lowest $\approx 150-200 \mathrm{~m}$ of the ABL during fair weather conditions. Thus, our measurement periods were focusing on fair weather conditions, with a predominant high-pressure system and clear skies during night, when it was expected that probing the lowest $150-200 \mathrm{~m}$ of the ABL was sufficient for $\mathrm{CH}_{4}$ budget calculations via the nocturnal boundary layer budgeting method.

\subsection{Vertical balloon profiles and ground surface measurements}

Tethered balloon measurements were performed at a distance of $150 \mathrm{~m}$ from the nearest farm buildings during the night in both years (2011 and 2012) with different temporal coverage (see Table 1 for details). A helium-filled blimp $\left(7.2 \mathrm{~m}^{3}\right.$; The Blimp Works Inc., Statesville, NC, USA) with a net lift of $4.35 \mathrm{~kg}$ carried a polyethylene inlet tube of $220 \mathrm{~m}$ length with inner diameter of $4 \mathrm{~mm}$ (Maagtechnic, Dübendorf, Switzerland) connected to a ground measurement station. The air sampled was drawn at a flow rate of $\approx 1 \mathrm{~L} \mathrm{~min}^{-1}$ (Reynolds number 344 ) to a fast greenhouse gas analyzer (FGGA; Los
Gatos Research Inc., Mountain View, CA, USA). With this approach it was possible to keep sensitive, heavy, and power consuming instrumentation on the ground at all times.

The precision of the $\mathrm{CH}_{4}$ concentration measurements, converted to $\mathrm{CH}_{4}$ dry mole fractions by the FGGA firmware, was $\sigma_{1 \mathrm{~s}}=1 \mathrm{ppb}$ and $\sigma_{\min }=0.15 \mathrm{ppb}$ at $1 \mathrm{~s}$ and $200 \mathrm{~s}$ integration time respectively. These values were determined from the Allan variance of a $1 \mathrm{~h}$ time series measured in a climate chamber under controlled conditions $(1927.7 \pm 1.1 \mathrm{ppb}$, $25^{\circ} \mathrm{C}, 40 \%$ relative humidity; data not shown).

Additional measurements of air temperature, atmospheric pressure, relative humidity, wind speed, and wind direction were carried out with meteorological tether sondes TS5A-SEN (Atmospheric Instrument Research, Inc., Boulder, USA), which were attached to the tether line. Each TS-5ASEN sonde contained a temperature and relative humidity probe in a horizontal radiation shield, with its opening facing the wind direction in order to vent the sensors. A pressure sensor allowed to determine the hydrostatic elevation above ground surface, and a cup anemometer determined horizontal wind speed. The wind direction was measured via a built-in compass attached to the tail of the TS-5A-SEN sonde that acted as a wind vane centred at the tether of the balloon.

These meteorological measurements were transmitted via an AIR IS-5A-RCR radio receiver $(395-410 \mathrm{MHz})$ to a Linux computer running an in-house software to collect data. The sondes and the radio receiver correspond to the instruments used in earlier studies (Eugster and Siegrist, 2000; Siegrist, 2001). Pressure $(\mathrm{hPa})$, temperature $\left({ }^{\circ} \mathrm{C}\right)$, and relative humidity $(\%)$ were transmitted with a resolution of two decimals, one decimal was transmitted for wind speed $\left(\mathrm{m} \mathrm{s}^{-1}\right)$, while wind direction $\left(^{\circ}\right)$ was transmitted in full numbers.

A nearby eddy covariance station provided micrometeorological measurements of air temperature, relative humidity, wind speed, wind direction, photosynthetic active radiation (PAR), and turbulence (Zeeman et al., 2010; Merbold et al., 2014), which were used for cross-referencing the meteorological tether sondes at times when the tethered balloon and the sondes were near the ground (ca. 1-2 m height). However, the accuracy of the sensors in the TS-5A-SEN sonde remained clearly below the resolution that the sondes transmitted their data, even after such an intercalibration. The manufacturer did not specify their accuracy, but experience showed that temperature, relative humidity, pressure, wind speed, and wind direction may be subject to uncertainties on the order of $\pm 0.2^{\circ} \mathrm{C}, \pm 3-5 \%, \pm 0.2 \mathrm{hPa}, \pm 0.2 \mathrm{~m} \mathrm{~s}^{-1}$, and $\pm 5^{\circ}$ respectively.

A GPS unit (eflight, SM-Modellbau.de, Germany) provided positioning and height information of the balloon system. In total, 18 soundings were conducted, of which 16 were used for further analysis, while 2 balloon soundings (16/17 August 2011 during 04:48 and 05:56 UTC+1) were rejected due to unfavourable meteorological conditions. Each ascent and descent of the remaining 16 soundings gave a mean vertical profile and a mean NBL budget flux (Ta- 
Table 1. Overview of the balloon measurements in 2011 and 2012 with the maximum height reached, the integration height in the time-height kriging interpolation, and the resulting averaged NBL budget fluxes (mean $\pm \mathrm{SD}$, where SD is the standard deviation of all $0.3 \mathrm{~h}$ time slices in the time-height kriging interpolation included in the calculation of the respective mean flux). The difference between two consecutive interpolated time slices was used to approximate the local derivative of concentration over time as detailed in Sect. 2.5.

\begin{tabular}{|c|c|c|c|c|c|c|}
\hline Date & Night & Sounding & $\begin{array}{r}\text { Time } \\
(\mathrm{UTC}+1)\end{array}$ & $\begin{array}{l}\text { Max. height } \\
\text { (ma.g.l.) }\end{array}$ & $\begin{array}{r}\text { Int. height } \\
\text { (m a.g.1.) }\end{array}$ & $\begin{array}{l}\text { NBL budget flux } \\
\left(\mu \mathrm{gCH}_{4} \mathrm{~m}^{-2} \mathrm{~s}^{-1}\right)\end{array}$ \\
\hline \multirow{5}{*}{$\begin{array}{l}\text { 16/17 Aug } \\
2011\end{array}$} & \multirow[t]{5}{*}{$\mathrm{N} 1$} & $\mathrm{~S} 1$ & $20: 47-21: 26$ & 140 & 50 & $1.27 \pm 0.85$ \\
\hline & & $\mathrm{S} 2$ & $21: 26-22: 01$ & 150 & 50 & $1.85 \pm 0.07$ \\
\hline & & $\mathrm{S} 3$ & $22: 01-22: 41$ & 150 & 50 & $1.55 \pm 0.48$ \\
\hline & & $\mathrm{S} 4$ & $22: 41-23: 30$ & 160 & 70 & $1.19 \pm 1.05$ \\
\hline & & S5 & $00: 48-01: 47$ & 150 & 50 & $1.13 \pm 0.06$ \\
\hline \multirow{4}{*}{$\begin{array}{l}24 / 25 \mathrm{Jul} \\
2012\end{array}$} & \multirow[t]{4}{*}{$\mathrm{N} 2$} & S6 & $20: 51-21: 24$ & 150 & 60 & $1.73 \pm 0.14$ \\
\hline & & S7 & $23: 27-23: 58$ & 150 & 50 & $2.37 \pm 0.72$ \\
\hline & & S8 & 01:05-01:37 & 130 & 110 & $2.88 \pm 0.61$ \\
\hline & & S9 & $05: 07-05: 37$ & 130 & 80 & $1.21 \pm 0.34$ \\
\hline \multirow{3}{*}{$\begin{array}{l}25 / 26 \text { Jul } \\
2012\end{array}$} & \multirow[t]{3}{*}{ N3 } & S10 & $20: 56-21: 16$ & 170 & 50 & $1.18 \pm 0.11$ \\
\hline & & S11 & $23: 03-23: 23$ & 160 & 50 & $1.68 \pm 0.05$ \\
\hline & & $\mathrm{S} 12$ & $01: 06-01: 22$ & 130 & 40 & $0.79 \pm 0.13$ \\
\hline \multirow{4}{*}{$\begin{array}{l}26 / 27 \text { Jul } \\
2012\end{array}$} & \multirow[t]{4}{*}{ N4 } & S13 & $20: 53-21: 14$ & 190 & 60 & $1.93 \pm 0.06$ \\
\hline & & S14 & $23: 03-23: 23$ & 180 & 120 & $1.84 \pm 0.09$ \\
\hline & & S15 & 01:01-01:25 & 180 & 50 & $1.52 \pm 0.01$ \\
\hline & & S16 & 03:07-03:29 & 170 & 60 & $1.53 \pm 0.12$ \\
\hline Overall mean & & & & & & $1.60 \pm 0.31$ \\
\hline
\end{tabular}

ble 1). All dates and times are given in central European time (UTC+1 h).

In order to also obtain a good data coverage of the nearsurface conditions where barometric height measurements of a tethered balloon tend to be not accurate enough, a guywired tower was installed next to the FGGA. Inlet tubes (Maagtechnic, Dübendorf, Switzerland) were installed on the tower at eight different heights $(0.2,0.5,1,2,3,5,8$, and $10 \mathrm{~m}$ a.g.1.), guiding the air into a home-built air inlet selection unit (Zeeman et al., 2008). The tower measurements were performed between balloon soundings, with each height being measured for $3 \mathrm{~min}$.

Two modes of operation with the tethered balloon were tested: during the 2011 campaign, conventional ascent/descent measurements were made using an ascent and descent velocity on the order of $0.15 \mathrm{~m} \mathrm{~s}^{-1}$. During the 2012 campaign, an attempt was made to keep the gas inlet at several fixed heights during the ascent to get a better quality of the measured concentration changes over time for these specific layer heights, at the expense of a poorer vertical resolution of the measurements.

\subsection{Budget flux calculation}

The NBL budget technique was applied at night during favourable weather conditions with clear skies and low wind speeds. In principle, nighttime conditions should allow to derive regional-scale average fluxes that can be compared to inventory estimates if the emission flux itself does not show a pronounced diel cycle, so that the diel cycle in concentrations measured in the lowest part of the NBL are primarily a function of (nocturnal vs. diurnal) atmospheric stability and stratification.

The budget flux $F_{\mathrm{S}}$, i.e. the average surface flux, can be expressed as follows (Denmead et al., 1996):

$F_{\mathrm{S}}=\int_{0}^{z_{i}} \frac{\partial \bar{c}}{\partial t} \mathrm{~d} z$,

where $\partial \bar{c} / \partial t$ is the rate of change in concentration with time, and $z_{i}$ is the NBL height. Overbars indicate averaging over time or space, depending on context. The resulting budget flux describes the accumulation of a scalar within the stable boundary layer at consecutive time steps. In practice, finite differences are used to approximate $\partial \bar{c} / \partial t$, which is expressed as $\Delta \bar{c} / \Delta t$ hereafter. We used time-space kriging to interpolate $\mathrm{CH}_{4}$ concentrations (see Sect. 2.5) from the tethered balloon and the $10 \mathrm{~m}$ tower.

The NBL budget method is based on the idea that during nights with ideal weather conditions, a stable nocturnal boundary layer develops, which is capped by a strong temperature inversion at its top that acts as a natural atmospheric chamber, accumulating all emissions of underlying sources (Mathieu et al., 2005; Pattey et al., 2006). Thus, the top of the NBL and hence $z_{i}$ will be characterized by 
$\Delta \bar{c} / \Delta t=0 \mathrm{ppm} \mathrm{s}^{-1}$ due to a neutral to unstable stratification with $\Delta \bar{\theta} / \Delta z \leq 0 \mathrm{~K} \mathrm{~m}^{-1}$. In our case, the budget flux computed with Eq. (1) is an integral measurement of the net flux from all relevant sources and sinks within the footprint of the balloon measurements. These relevant components can be specified in more detail by

$F_{\mathrm{s}}=F_{\text {soil }}+F_{\text {ent }}+F_{\mathrm{HA}}+F_{\text {other }}$,

where $F_{\text {soil }}$ is the soil exchange flux, $F_{\text {ent }}$ the entrainment flux at the top of the NBL, $F_{\mathrm{HA}}$ the horizontal advection, and $F_{\text {other }}$ the flux resulting from emissions of other sources in the footprint. Under stationary conditions with a constant NBL height, $F_{\text {ent }}$ becomes negligible. At the Chamau site, earlier chamber flux measurements showed that $F_{\text {soil }}$ is a small component $\left(-0.0024 \mu \mathrm{g} \mathrm{CH}_{4} \mathrm{~m}^{-2} \mathrm{~s}^{-1}\right.$ on average; Imer et al., 2013) representing typically less than $1 \%$ of the expected $F_{\mathrm{s}}$ and hence can be neglected in Eq. (2). This minor role of the source and sink strengths of upland grasslands in the total greenhouse gas budget of a farm has also been found at other sites (e.g. Hartmann et al., 2011, range -0.015 to $0.013 \mu \mathrm{g} \mathrm{CH}_{4} \mathrm{~m}^{-2} \mathrm{~s}^{-1}$ for single chamber measurements) and in incubation studies (e.g. Wang et al., 1999, maximum uptake of $-0.016 \mu \mathrm{g} \mathrm{CH}_{4} \mathrm{~m}^{-2} \mathrm{~s}^{-1}$ during first $8 \mathrm{~h}$ of incubation at $24^{\circ} \mathrm{C}$ ). Furthermore, the advection term can be neglected if measurements are taken over a horizontally sufficiently large and flat terrain with a homogeneous source distribution (Raupach et al., 1992; Choularton et al., 1995; Fowler et al., 1996; Beswick et al., 1998; Denmead et al., 2000; Cleugh et al., 2004; Mathieu et al., 2005; Pattey et al., 2006). With these simplifications, Eq. (2) can be reduced to

$F_{\mathrm{s}} \approx F_{\text {other }}$,

where $F_{\text {other }}$ in our case represents $\mathrm{CH}_{4}$ emissions from the cattle and their products stored at the Chamau farmstead.

Nevertheless, it has been shown elsewhere that even under stable conditions, small advective effects and wind direction play an important role in determining the NBL budget (Lowry et al., 2001; Zinchenko et al., 2002; Hsu et al., 2010). Advected air parcels can include pollutants from sources lying in the upwind fetch and hence can bias the local $\mathrm{CH}_{4}$ concentrations, resulting in an overestimation of the NBL budget. In particular, nighttime measurements can include regional information of up to several kilometres upwind (Bamberger et al., 2014). In order to avoid the impact of emissions from upwind sources and to reduce the measurement footprint to an extent, which only includes the barn buildings of the Chamau farmstead, the integration height was set to the height where $\Delta \bar{\theta} / \Delta z \leq 0 \mathrm{~K} \mathrm{~m}^{-1}$ (Mathieu et al., 2005; Pattey et al., 2006) with $\theta$ being the potential temperature $\left(\theta=T\left(p_{0} / p\right)^{1.402}\right.$ with $p_{0}=1000 \mathrm{hPa}$ and $p$ ambient pressure). In addition, only measurements with an average wind direction from the SSE-SW $\left(157.5-225^{\circ}\right)$ sector were used for the flux calculation, i.e. where the main barn building of the Chamau station and the grazed pastures were located. During very calm weather conditions when mean wind speeds reached $0 \mathrm{~m} \mathrm{~s}^{-1}$, measurements were not restricted to wind directions. The impact of neglected horizontal advective processes on the overall NBL budget estimates will be part of the discussion section.

\subsection{Inventory estimates}

Two inventory estimates of $\mathrm{CH}_{4}$ emissions exist for Switzerland (i.e. NIR and SEI), which both use the same estimation methodology, but differ in their spatial resolution. While the NIR evaluated $\mathrm{CH}_{4}$ emissions on an annual basis for entire Switzerland (FOEN, 2015), the recently developed SEI (Hiller et al., 2014a) distributed the $\mathrm{CH}_{4}$ emissions, based on the 2007 year stocking census data (FSO, 2009), onto a $500 \mathrm{~m} \times 500 \mathrm{~m}$ grid according to Swiss land use statistics (FSO, 2007) and then scaled the emissions to represent 2011 livestock numbers (see Hiller et al., 2014a). Both inventories estimate the $\mathrm{CH}_{4}$ emissions from national livestock numbers multiplied with animal-specific emission factors, i.e. the $\mathrm{CH}_{4}$ conversion rate for enteric fermentation $y_{m}$ and the $\mathrm{CH}_{4}$ conversion factor for manure management, which are both given by the IPCC Good Practice Guidance (Soliva, 2006; ART, 2012).

The SEI accounts for the large spatial heterogeneity of $\mathrm{CH}_{4}$ sources, which the NIR cannot resolve. In the SEI, the Chamau research station was explicitly resolved by several grid cells, with $\mathrm{CH}_{4}$ emissions ranging from 6 to $820 \mathrm{~kg} \mathrm{CH}_{4} \mathrm{ha}^{-1} \mathrm{yr}^{-1}$. This large variation among the individual grid cells arises due to the standardized assignment process of the SEI: about $80 \%$ of the $\mathrm{CH}_{4}$ emissions are assigned to the grid cell with the main building of a farmstead, while the remaining emissions are evenly distributed to the pasture area of the entire municipality (Hiller et al., 2014a).

In order to compare inventory estimates to budget fluxes, the NIR estimates of enteric fermentation $(119 \pm 21.5 \mathrm{Gg}$ $\left.\mathrm{CH}_{4} \mathrm{yr}^{-1}\right)$ and manure management $\left(31 \pm 17 \mathrm{Gg} \mathrm{CH}_{4} \mathrm{yr}^{-1}\right)$ for the year 2011 were disaggregated to the area used for pastures (here $5685.8 \mathrm{~km}^{2}$ ), according to the CORINE land use map (FSO, 1998). For the SEI, the grid cell representing the main building of the research station was used for comparison.

To overcome the inconsistencies in spatial resolution and temporal representativeness of both the NIR and the SEI, we specifically estimated $\mathrm{CH}_{4}$ emissions for the Chamau farmstead (in the following called CHAI as an acronym for CHAmau Inventory estimate), using the same EFs as for the SEI but multiplied with actual stocking densities of the respective measurement periods. This simplified the validation, as livestock represents the main $\mathrm{CH}_{4}$ source at the Chamau station and, hence, the emission of the whole farmstead is included in the CHAI estimates without the need for spatial disaggregation. The CHAI inventory estimates include different animal headcounts for the years 2011 and 2012. In 2011, 55 dairy cattle, seven non-dairy cattle, nine young cattle, 18 sheep, and 129 swine were located at the Chamau 
farmstead. The inventory estimate for 2012 includes besides 81 dairy cattle, two non-dairy cattle, 18 young cattle, eight sheep, 47 swine, and 39 goats. Since no uncertainty estimates existed for the SEI and CHAI, we assumed the same methodology-specific uncertainty as for the NIR. The systematic uncertainty due to the spatial disaggregation of the SEI remains unknown. The standard deviation of all three inventory estimates (i.e. NIR, SEI, and CHAI) was calculated as the average uncertainty estimates of enteric fermentation $(18.1 \%)$ and manure management $(54.4 \%)$ from the NIR (FOEN, 2015), yielding $36.3 \%$.

\subsection{Data processing and general conventions}

Data processing, analysis, and flux calculations were done with the statistics software package R, version 2.15.1 (R Core Team, 2014). Nighttime data were defined as PAR $<20 \mu \mathrm{mol}$ $\mathrm{m}^{-2} \mathrm{~s}^{-1}$. Ordinary kriging using the geoR-package was performed for spatiotemporal interpolation of $\mathrm{CH}_{4}$ concentrations and served as a basis for flux calculations.

Before kriging, the time stamps of the tethered balloon system and the $10 \mathrm{~m}$ tower system were synchronized. The grid spacing for the kriging was chosen to be $0.3 \mathrm{~h}$ along the time axis in both years. In the vertical direction, the grid spacing was set to $0.2 \mathrm{~m}$ between 0 and $10 \mathrm{~m}$ a.g.l., where tower profile data were used, and to $5 \mathrm{~m}$ between $10 \mathrm{~m}$ and $200 \mathrm{~m}$ a.g.l., where tethered balloon data were used. In practice, the maximum height that could be reached with the $220 \mathrm{~m}$ hose attached to the tethered balloon was roughly $150 \mathrm{~m}$ a.g.l. Horizontal drift with the mean wind and dew formation on the balloon - lowering payload capacity - were responsible for this height limit.

NBL budget flux calculations were restricted to the selection criteria mentioned in Sect. 2.3. Based on the kriged time-height concentration field, the NBL budget flux was calculated separately for each of the balloon soundings using the full duration of each sounding $\pm 30 \mathrm{~min}$. In practice, the difference between two consecutive time slices was used to approximate the local derivative of concentration over time (in ppm s${ }^{-1}$ ), from which the fluxes could be computed by multiplying that value with the thickness of the layer $(\mathrm{m})$ and summing up over the NBL extent covered by measurements and interpolated values. These raw fluxes (in $\mathrm{ppm} \mathrm{m} \mathrm{s}^{-1}$ ) were then converted to $\mu \mathrm{g} \mathrm{CH}_{4} \mathrm{~m}^{-2} \mathrm{~s}^{-1}$ by taking the actual molar density of air into account (computed from ambient pressure and temperature), and the molar mass of $\mathrm{CH}_{4}$. If not stated otherwise, reported values denote means \pm standard deviations. The terms N1-N4 and S1-S16 refer to the different nights and soundings in the respective years (Table 1).

An uncertainty assessment (Sect. 4.1) was performed which also included heights above $200 \mathrm{~m}$ up to a $z_{i}$ of $400 \mathrm{~m}$, which is $2.5 \times$ the typical NBL inversion heights observed by Messerli (1992) and Utiger (1992). Since these heights were above the maximum height reached by the tethered balloon system, the following approach was employed.
A background concentration was determined from the minimum $\mathrm{CH}_{4}$ concentration observed during each field campaign (diurnal and nocturnal data). Between $200 \mathrm{~m}$ (top level of kriged interpolation) and the background at a predefined $z_{i}>200 \mathrm{~m}$, a linear decrease in $\mathrm{CH}_{4}$ concentrations with height was assumed. This is probably overestimating the true rate of concentration changes at heights $>200 \mathrm{~m}$ (which may follow an exponential rather than linear decrease with height), and hence our uncertainty estimate should be considered a conservative estimate of potential systematic errors in NBL budget flux estimates in cases where the determination of $z_{i}$ remains highly uncertain.

\section{Results}

\subsection{Weather conditions and diel course of methane concentrations}

During our measurements in 2011 and 2012, the weather was dominated by a high-pressure system over central Europe. We experienced warm and dry daytime conditions with temperatures reaching $302.1 \mathrm{~K}$ in 2011 and $306.1 \mathrm{~K}$ in 2012 and a pronounced surface cooling with clear skies and low wind speeds during all nights (Fig. 1). Radiative cooling (i.e. $\Delta \bar{T} / \Delta t \leq 0 \mathrm{~K} \mathrm{~h}^{-1}$ ) was most pronounced immediately after sunset, providing sufficient atmospheric stability and stationarity for the build-up of a NBL. Later during the nights, cooling rates remained negative and enabled the deepening of the stable NBL. The nighttime cooling was most pronounced during N1 in $2011(286.1 \mathrm{~K})$, whereas air temperatures in N2-N4 in 2012 did not fall below $287.1 \mathrm{~K}$, with the highest nighttime value of $288.7 \mathrm{~K}$ being observed during N4. All nights were dominated by low near-surface wind speeds $<1 \mathrm{~m} \mathrm{~s}^{-1}$, associated with very weak turbulence with friction velocities $u_{*}<0.08 \mathrm{~m} \mathrm{~s}^{-1}$. In 2012, however, some measurement periods experienced slightly increased wind speeds and friction velocities, probably due to weak advection promoting mixing processes within the stable NBL.

The diel courses of $\mathrm{CH}_{4}$ concentrations mainly followed the meteorological conditions. Due to convective mixing during daytime, $\mathrm{CH}_{4}$ concentrations remained relatively low $(\approx 1.9 \mathrm{ppm})$. At night, concentration values increased as the emissions were trapped within the smaller volume of the stable NBL (exemplarily shown for N1, Fig. 2a). Highest mixing ratios, here up to $3.1 \mathrm{ppm}$, were observed around 03:00 LT at the lowest measurement height close to the surface (i.e. $0.2 \mathrm{~m}$ a.g.l.) due to inhibited vertical mixing. For lower measurement heights, the nighttime accumulation of $\mathrm{CH}_{4}$ started after sunset. Measurements taken from above $70 \mathrm{~m}$ a.g.l., however, only showed an increase in $\mathrm{CH}_{4}$ concentrations during the second half of the night, resulting in a less pronounced diel pattern compared to lower elevations (Fig. 2b). Besides reaching the top of the NBL at about $70 \mathrm{~m}$ a.g.1., variable wind directions affected the nocturnal in- 


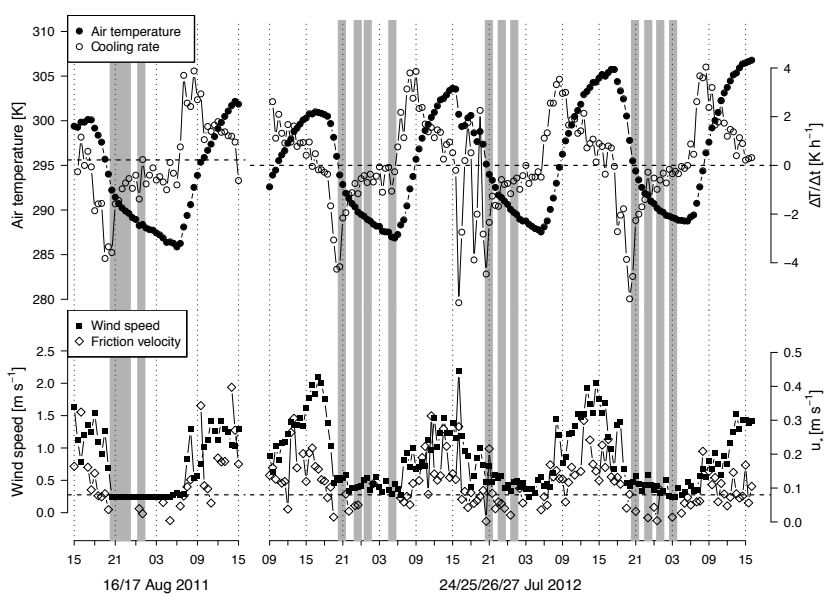

Figure 1. Meteorological conditions at Chamau (30 min averages) during the balloon measurements (grey shaded areas) in 2011 and 2012. Top panel: air temperature and cooling rates $\Delta \bar{T} / \Delta t$ at $2 \mathrm{ma.g.1}$; bottom panel: wind speed and friction velocity $u_{*}$ at $2 \mathrm{ma.g.l}$. Dashed horizontal lines show the cooling rate threshold of $0 \mathrm{~K} \mathrm{~s}^{-1}$ in the top panel and the threshold of low mechanical turbulence $u_{*}<0.08 \mathrm{~m} \mathrm{~s}^{-1}$ (Zeeman et al., 2010) in the lower panel.

crease in $\mathrm{CH}_{4}$ concentrations. The nighttime $\mathrm{CH}_{4}$ build-up was most pronounced when air masses originated from the wind sector between 180 and $270^{\circ}$, including the cattle barn buildings (in Fig. 2b, at heights below $50 \mathrm{~m}$ a.g.1. from 21:00 to 23:00 LT). In contrast, air masses with a northern wind component, here above $100 \mathrm{~m}$ a.g.l., showed constant or decreasing $\mathrm{CH}_{4}$ concentrations during the same measurement period.

\subsection{Vertical balloon profiles}

Potential temperature gradients of successive vertical balloon profiles indicated stable conditions during all nights (i.e. $\Delta \bar{\theta} / \Delta z>0 \mathrm{~K} \mathrm{~m}^{-1}$ ) and hence the establishment of a stable NBL (Fig. 3a). However, the height of this NBL, where a transition from stable to neutral or unstable conditions is expected, strongly varied among the individual profiles. Half of the profiles revealed a temperature inversion at or above $100 \mathrm{~m}$ a.g.1. (i.e. S1 and S3 of N1; S7 and S8 of N2; S12 of N3; S14, S15, and S16 of N4). The other half exhibited multiple transition heights, pointing to the development of multiple stable layers within the NBL. Only few soundings (i.e. S5 of N1; S6 of N2; S13 of N4) showed a clear temperature inversion (at 50-60 m a.g.l.), followed by a second stable layer with positive temperature gradients with increasing elevation. Other soundings were rather marked by a gradual transition from stable to neutral conditions (e.g. S10 and S11 of N3). However, temperature gradients among individual soundings differed markedly, indicating a temporal evolution (e.g. growth, consolidation, or separation) of the different layers within the NBL.

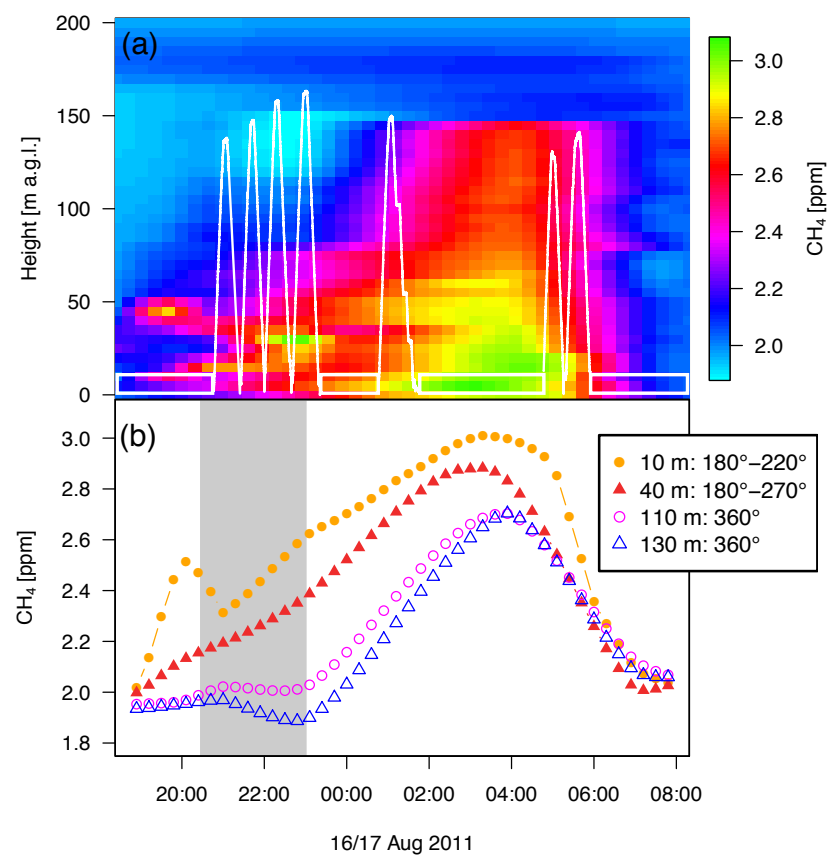

Figure 2. (a) Kriged time-space interpolation of the $\mathrm{CH}_{4}$ concentrations obtained from the balloon and near-surface $(0-10 \mathrm{~m})$ measurements during 16/17 August 2011, including rejected measurements not used for NBL budget estimates. Vertical and horizontal kriging directions were equally weighted, resulting sometimes in sharp vertical concentration changes. The balloon position is shown with a white line, whereas the near-surface concentration measurements are shown with a white box. (b) Nocturnal course of $\mathrm{CH}_{4}$ concentrations at 10, 40,110, and $130 \mathrm{~m}$ a.g.l.: the grey shaded time period shows the period when the wind direction changes from easterly (around 20:00) to south-westerly winds (180-270 ${ }^{\circ}$, downvalley direction) near the surface and anti-wind (in opposite direction) aloft (see legend for details). This clear separation between the down-valley wind and its anti-wind during the August 2011 campaign explains why a relatively low $z_{i}$ of only $50 \mathrm{~m}$ resulted for the integration of the NBL budget fluxes (see Table 1).

The $\mathrm{CH}_{4}$ concentration profiles showed quite different patterns between the 2 years. In 2011 (S1-S5), the profiles exhibited a clear increase in mixing ratios from $\mathrm{S} 1$ to $\mathrm{S} 5$ within the lowest $100 \mathrm{~m}$, and all profiles reached a background value of $\approx 2$ ppm above $100 \mathrm{~m}$ a.g.l. (Figure $3 \mathrm{~b}$ ), pointing to the main NBL inversion height. This drop in concentration was associated with a change in wind direction from SSW to N and an increase in wind speeds up to $4 \mathrm{~m} \mathrm{~s}^{-1}$ (Fig. 3c). In 2012 (S6 to S16), all profiles indicated a well-mixed NBL with small or even absent vertical concentration gradients but with a substantial increase in concentration over time (Fig. 3b). Even though temperature inversions were present, none of the $\mathrm{CH}_{4}$ concentration profiles reached a background value at or above the inversion height. The same well-mixed conditions were found for the two rejected soundings in 2011. However, no clear changes in wind direction could be observed in the profiles from 2012. Most wind profiles me- 


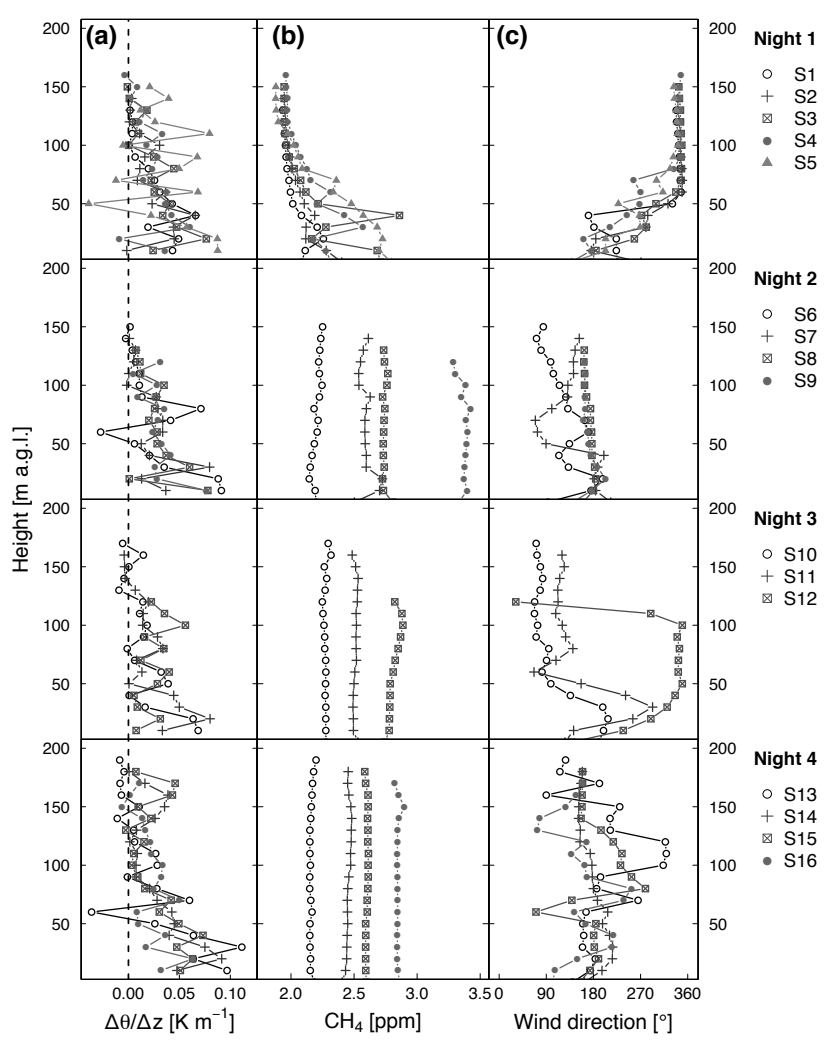

Figure 3. Vertical profiles of (a) potential temperature gradients, (b) $\mathrm{CH}_{4}$ concentrations, and (c) wind directions of the individual balloon soundings. The dashed vertical lines indicate neutral stratification in (a) and lower and upper wind direction limits used for the NBL budget flux calculation in (c).

andered between a WSW sector in the lower part of the NBL and an ESE sector in the upper part of the NBL. Only S12 of $\mathrm{N} 3$ showed an abrupt change in wind direction from SE to N at $50 \mathrm{~m}$ a.g.l. Wind speed in 2012 showed a slightly different picture compared to 2011 as well (data not shown). Except S6 and S8 of N2, all profiles revealed increasing wind speeds with height. Some soundings also showed a peak with maximum wind speeds (i.e. S9 of N2 at $80 \mathrm{~m}$ a.g.l.; S11 of N3 at $130 \mathrm{~m}$ a.g.l.; S14 and S15 of N4 at 140 and $50 \mathrm{~m}$ a.g.l. respectively), indicative of an active low-level jet.

\subsection{NBL budget fluxes and comparison to inventory estimates}

The observed $\mathrm{CH}_{4}$ concentration and potential temperature gradients showed that the overall NBL at Chamau was not merely influenced by local emissions from the farmstead. The well-mixed $\mathrm{CH}_{4}$ concentration profiles in 2012 suggested that the NBL was primarily influenced by emissions from sources further upwind, which were already well mixed with ambient air, and that local sources only had a minor influence. Restricting the NBL budget either to the height where $\Delta \bar{\theta} / \Delta z \leq 0 \mathrm{~K} \mathrm{~m}^{-1}$ and/or to wind directions originat- ing from the SSE-SW sector allowed the separation of emissions from the Chamau station vs. emissions from upwind lying sources (see Sect. 2.3). The resulting NBL budget fluxes of the individual profiles varied between $0.79 \pm 0.13$ and $2.88 \pm 0.61 \mu \mathrm{g} \mathrm{CH}_{4} \mathrm{~m}^{-2} \mathrm{~s}^{-1}$ during the different nights (Table 1), with an overall mean of $1.60 \pm 0.31 \mu \mathrm{g} \mathrm{CH}_{4} \mathrm{~m}^{-2} \mathrm{~s}^{-1}$. All nights showed a clear nocturnal course of NBL budget fluxes, with higher fluxes in the middle of the night and lower fluxes shortly after sunset and before sunrise. This nocturnal course was most pronounced during N2 and N3 in 2012 due to a larger difference in consecutive temperature and $\mathrm{CH}_{4}$ profiles.

Inventory estimates of the Chamau farmstead varied markedly among the different inventories (Table 2). Highest values were derived for CHAI with $1.29 \pm 0.47$ and $1.74 \pm 0.63 \mu \mathrm{g} \mathrm{CH} \mathrm{CH}_{4} \mathrm{~m}^{-2} \mathrm{~s}^{-1}$ in 2011 and in 2012 respectively. Lower emission fluxes of $0.83 \pm 0.30 \mu \mathrm{g} \mathrm{CH}_{4} \mathrm{~m}^{-2} \mathrm{~s}^{-1}$ (for all nights in both years) resulted from the spatial disaggregation of the NIR estimates. The SEI emission flux estimate for the grid cell including the main building of the farmstead, however, was only $0.42 \pm 0.15 \mu \mathrm{g} \mathrm{CH}_{4} \mathrm{~m}^{-2} \mathrm{~s}^{-1}$, significantly lower than the CHAI estimates. These CHAI estimates, representing the same spatial extent as the main SEI grid cell, were therefore at least 3 times higher than the SEI, although $80 \%$ of total $\mathrm{CH}_{4}$ emissions from the Chamau farmstead was covered by this main grid cell. Mean NBL budget fluxes for the different nights ranged from $1.40 \pm 0.50$ to $2.05 \pm 0.45 \mu \mathrm{g} \mathrm{CH}_{4} \mathrm{~m}^{-2} \mathrm{~s}^{-1}$ and were comparable to the CHAI estimates (Table 2).

\section{Discussion}

\subsection{Flux uncertainty assessment}

The determination of the NBL budget flux using Eq. (1) involved the estimation of the inversion height $z_{i}$ which was considered the top of the relevant layer for the integration of concentration changes to derive $F_{\mathrm{s}}$. It was, however, not always easy to determine $z_{i}$ accurately from available tethered balloon data, namely in cases where the balloon did not clearly rise beyond $z_{i}$. Hence, we performed an assessment of the uncertainty of our flux estimates with the NBL budget method. We used the criteria $\Delta \bar{c} / \Delta t=0 \mathrm{ppm} \mathrm{s}^{-1}$ under neutral to unstable stratification with $\Delta \bar{\theta} / \Delta z \leq 0 \mathrm{~K} \mathrm{~m}^{-1}$ for integration of Eq. (1). Therefore, we used relative humidity as an independent variable to assess the uncertainty in our estimate.

During the first part of the night on 16 August 2011 with a growing NBL after 21:30 (Fig. 4a), the bottom measurement before launching the tethered balloon showed $100 \%$ relative humidity, and hence the marked transition from the saturated near-surface layer to the drier air aloft was clearly seen in both ascents and descents of the balloon. As expected, $z_{i}$ estimated from ascents did not exactly match the values 
Table 2. Farm-scale $\mathrm{CH}_{4}$ emission estimates from different inventories (NIR, SEI, and CHAI) and the NBL budget approach. The inventory estimates are based on the methodology recommended by the IPCC (see text for details). CHAI estimates use current stocking census data, whereas NIR and SEI estimates are both based on 2011 stocking census data. NBL budget fluxes are denoted as the mean of all budget fluxes from the individual balloon profiles of the respective nights. The fluxes are in $\mu \mathrm{g} \mathrm{CH}_{4} \mathrm{~m}^{-2} \mathrm{~s}^{-1}$ (mean $\pm \mathrm{SD}$ ).

\begin{tabular}{llrrrr}
\hline Year & Campaign & NIR & SEI & CHAI & NBL \\
\hline \multirow{2}{*}{2011} & 16/17 August 2011 & & & & $1.40 \pm 0.50$ \\
& & $0.83 \pm 0.30$ & $0.42 \pm 0.15$ & $1.29 \pm 0.47$ & $1.40 \pm 0.50$ \\
\hline & 24/25 July 2012 & & & $2.05 \pm 0.45$ \\
& 25/26 July 2012 & & & $1.22 \pm 0.10$ \\
\multirow{2}{*}{2012} & 26/27 July 2012 & & & & $1.70 \pm 0.07$ \\
\hline
\end{tabular}

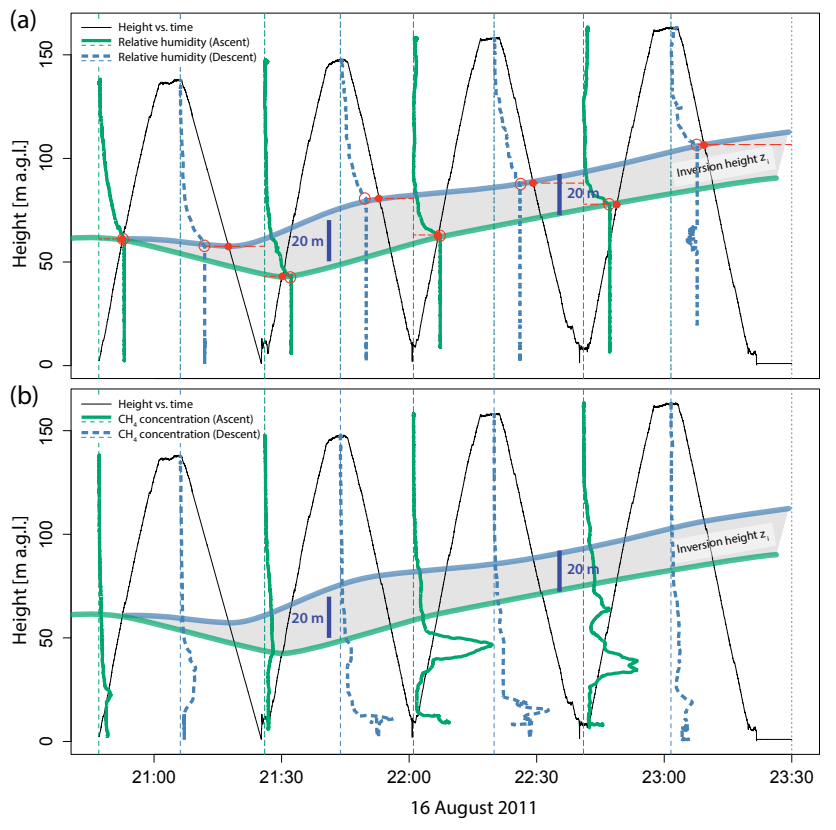

Figure 4. Inversion height $z_{i}$ (a) approximated via the profile of relative humidity for ascents (bold solid lines) and descents (bold dashed lines) during the first four nocturnal tethered balloon profiles and (b) with vertical profiles of $\mathrm{CH}_{4}$ concentrations superimposed. The balloon height is shown as a time trace (black line). The relative humidity was $100 \%$ at the ground surface and the minimum value observed in a profile was used as a reference (thin dashed vertical lines) placed at the time point of the beginning of ascents and descents respectively. The large and small red circles in (a) link the relative humidity showing the top of the saturated surface layer (large circles) with the corresponding height and time point on the black curves (small circle with red horizontal dashed line). The inversion height $z_{i}$ is derived separately for ascents and descents, yielding the grey band of showing an uncertainty on the order of 20-30 $\mathrm{m}$ for $z_{i}$.

derived from consecutive descents (Fig. 4a), but, contrary to initial expectations, $z_{i}$ derived from ascents was lower than values derived from descents, with a difference of typically up to $20-30 \mathrm{~m}$. This means that even with a slow ascent $\left(0.16 \pm 0.03 \mathrm{~m} \mathrm{~s}^{-1}\right.$, mean \pm standard deviation $)$ and slow de- scent $\left(-0.14 \pm 0.03 \mathrm{~m} \mathrm{~s}^{-1}\right)$ in the example in Fig. $4 \mathrm{a}$, the ascending balloon seemed to perturb the stable atmosphere in a way that the drier air aloft was mixed down to the sensor as the balloon rose, whereas during the descent the sensor first crossed $z_{i}$, followed by the balloon, which explained the higher $z_{i}$ values measured during descents.

Thus, similarly to what was seen with relative humidity, it must be expected that there was some unavoidable mixing of $\mathrm{CH}_{4}$ in the vertical profiles probed by the tethered balloon that translated to uncertainties in computing the NBL volume budget, both via (a) uncertainties of determining the exact height from where a gas sample originated in the vertical profile and (b) from the associated uncertainty in determining $z_{i}$ from tethered balloon soundings. As long as the prominent features of increased $\mathrm{CH}_{4}$ concentrations in the vertical profile mostly remained below $z_{i}$ as determined from relative humidity (Fig. 4b), the NBL budget fluxes are expected to be rather robust against uncertainties in $z_{i}$. The small-scale layer structures evolving in the NBL are in fact emission plumes that spread horizontally at a constant buoyancy level (see Fig. 4b), difficult to predict from local measurements alone. The unknown variability of such plumes between two subsequent balloon soundings appeared to be the most problematic source of uncertainty in NBL budget flux estimates.

To assess the uncertainty involved in the NBL budget flux estimates presented in Sect. 3.3 and Table 1, we also calculated the range of fluxes that would result from fixed inversion heights (and thus integration heights) $z_{i}$ of 50, 100, $150,200,300$, and $400 \mathrm{~m}$, using all tethered balloon sounding data (Fig. 5). In addition to uncertainties in determining $z_{i}$, the effect of extrapolating available data beyond the extent of the maximum height of an actual sounding was assessed (green circles in Fig. 5). For comparison, we repeated all calculations with the subsets of data obtained from ascents and descents only (not shown).

Using both ascents and descents in flux calculations (Fig. 5) was very comparable to using ascents only or descents only (not shown). Ascents led to a slightly lower sensitivity of flux calculations to $z_{i}$ estimates, whereas calculations based only on descents showed a higher sensitivity. In 


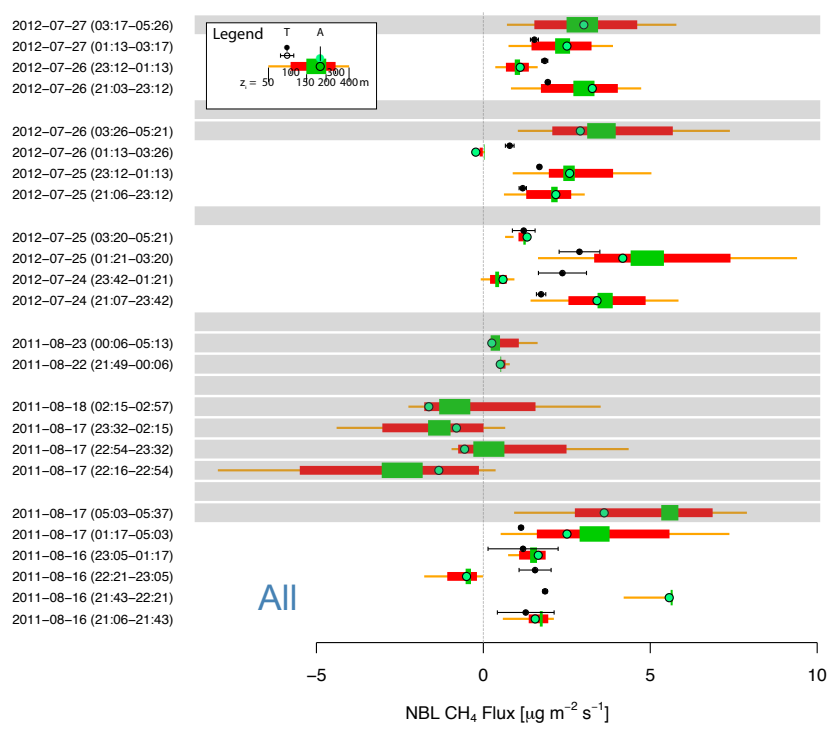

Figure 5. Sensitivity of NBL budget flux calculations on $z_{i}$ used as the upper boundary of integration in Eq. (1) using data from all soundings (one ascent and one descent taken as one sounding). The colour bars show the range of fluxes resulting if $z_{i}$ is uncertain between 50 and $400 \mathrm{~m}$ (thin orange line), between 100 and $300 \mathrm{~m}$ (red medium line), or between 150 and $200 \mathrm{~m}$ (bold green line) using interpolated data (see Sect. 2.5). The circles (A) show the NBL budget flux that was achieved when no extrapolation was done beyond the height range that was actually measured, and the black disks and error bars (T) show the values presented in Table 1 following the method described in Sect. 2.3. Soundings with a grey background were considered nonstationary and were not used in this study.

principle, we expected the reverse: when a tethered balloon was lowered into the stable atmosphere below it, the meteorological sensors and gas inlet penetrated the stable layer first, followed by the disturbance of the balloon. Hence it was not entirely clear why the ascents appeared to perform better than the descents, and thus we used both ascents and descents in combination to avoid adding unnecessary bias to our calculations.

In cases of nonstationary conditions - which were quite frequent during calm nights - the systematic uncertainty was so large that not even the sign of the flux estimate was certain, which led to a substantial number of soundings that had to be discarded from the analyses (grey bands in Fig. 5). Thus, although there are certainly further components that add to random uncertainty in our estimates, the two main issues to overcome in future projects are (i) extending the vertical layer over which high-quality concentration measurements can be made and (ii) using profiling at slow but steady ascent rates to obtain consistent vertical profiles of all meteorological variables, which better allow detection of nonstationary conditions and clearly include the transition across $z_{i}$, which is a critical value in flux estimates. Even with limited payload it may be advisable to have to tethersondes at- tached to the balloon tether, one which measures the conditions 50-100 m above the tube inlet (of limited length) and another at the height of the tube inlet. In such a way at least conditions where concentration measurements close to $z_{i}$ are covered, the upper tethersonde would allow to establish that these measurements were actually close to $z_{i}$. In most cases a distinct drop in relative humidity is a clear sign of $z_{i}$.

\subsection{Using the NBL budget approach in complex terrain}

In contrast to other studies using the NBL budget approach at horizontally homogeneous and flat sites, our measurements were located in complex terrain with variable NBL structures. Temperature, $\mathrm{CH}_{4}$ concentration, and wind profiles showed that the NBL in the Reuss Valley underwent a significant temporal evolution, with the establishment of multiple stable layers and with a high dependency on wind direction. With its location north of the Swiss pre-Alps, the NBL was primarily affected by the valley wind system and the resulting thermodynamic processes in the atmosphere. The complex temporal evolution of our temperature, wind direction, and wind speed profiles (Fig. 3) suggested different disturbances (e.g. advection of air with higher $\mathrm{CH}_{4}$ concentration, pulsating down-valley flows, cold air drainage), leading to turbulent mixing events within the lower and upper parts of the NBL. These disturbances finally resulted in well-mixed $\mathrm{CH}_{4}$ concentration profiles throughout the NBL in 2012 and also in the rejected profiles in 2011, although clear vertical concentration gradients were expected due to the observed temperature inversions. These findings suggested that advection and mixing processes played a prominent role during our measurements. In addition, turbulence and wind speed measurements of our eddy covariance system suggested that intermittent turbulent processes affected the thermodynamic structure of the boundary layer. Although local meteorological conditions favoured the build-up of a stable and stratified NBL, turbulent processes within the NBL have also been reported by other studies (Parker and Raman, 1993; Holden et al., 2000; Mahrt and Vickers, 2002; Wang et al., 2006). In addition, some of our wind speed profiles indicated the presence of a low-level jet, which - besides cold air drainage had a significant impact on vertical transport within the NBL (Mathieu et al., 2005; Pinto et al., 2006; Sun et al., 2007). Hence, similar to Dorninger et al. (2011), the temporal evolution of the NBL in the Reuss Valley was primarily affected by local-scale mixing processes.

Besides intermittent turbulence, advection processes challenge the applicability of the NBL budget approach for a feasible estimation of farm-scale $\mathrm{CH}_{4}$ emissions. Although studies so far have focused on the regional scale with homogeneously distributed sources and hence neglected the advection term in the $\mathrm{CH}_{4}$ budget, advection has also been reported in other studies as an important factor of the resulting budget flux (Kuck et al., 2000; Pattey et al., 2006). Since we had neglected horizontal advection by assuming $F_{\mathrm{HA}} \approx 0$, 
our NBL budget fluxes represented $F_{\text {other }}$. However, the $\mathrm{CH}_{4}$ concentration and wind direction profiles suggested that $\mathrm{CH}_{4}$ concentrations largely depended on wind direction (Fig. 2b). This indicated a heterogeneous distribution of $\mathrm{CH}_{4}$ sources in the Reuss Valley and hence $F_{\mathrm{HA}} \neq 0$, even though major parts of its relatively broad basin are used for agriculture. In addition, it has been shown that even nighttime observations measured at very low elevations above ground ( $2 \mathrm{~m}$ a.g.l.) carry regional information up to $200 \mathrm{~km}^{2}$ (Bamberger et al., 2014). An application of the NBL budget approach with $F_{\mathrm{HA}} \approx 0$, as often done in other studies, will thus result in budgets which represent an enlarged spatial extent not limited to the Chamau farmstead. Furthermore, the fluxes would include horizontally advected air parcels that carry a $\mathrm{CH}_{4}$ concentration signal that reflects different rates of agricultural emissions than those from the Chamau farmstead. Therefore, in order to estimate emissions at a farm scale, we minimized uncertainties caused by horizontal advection from sources further upwind of the Chamau farmstead by carefully selecting the integration height of the NBL budget flux calculation within specific wind direction and wind speed conditions (see Sect. 2.3). This ensured that the main factor affecting the measurements was kept to the Chamau farmstead and hence reduced the influence of upwind lying sources through advection. Still, since the upper limit of the NBL height was not reached in 2012 and the well-mixed $\mathrm{CH}_{4}$ concentration profiles pointed to the presence of advective processes, the emissions from sources further upwind might have had an impact on the resulting NBL budget estimate. Therefore, the uncertainty in flux estimates introduced by assumptions necessary with respect to $z_{i}$ and the time-space interpolation between soundings (Sect. 4.1) revealed some limits of the NBL budget approach that will require further attention in future studies.

Overall, a good agreement of the NBL budget fluxes with the CHAI estimates could be achieved which confirmed the viability of our selection criteria. Still, not all advective effects and external sources could be accounted for, as the NBL budget fluxes showed both a clear day-to-day and a nocturnal variability (Tables 1 and 2, Fig. 5), which could not simply be explained by the diel course of livestock $\mathrm{CH}_{4}$ production. Thus, the NBL budget approach not only integrates over a larger spatial scale but can also be used to resolve mixing processes on smaller, i.e. hourly, timescales.

\subsection{Validating inventory estimates}

The validation of inventory emission estimates via atmospheric measurements is not a trivial task. The main challenge lies in matching the different spatial and temporal scales of the inventories and the measurements. The inventory estimates represent annual means, which can deviate substantially from measurements taken at any given time. Seasonally changing farming practices and temporal variability in $\mathrm{CH}_{4}$ emissions are not resolved within a typical inventory so far and can only be covered by direct measurements. Additionally, the coarse resolution of the statistical database in SEI impaired a reliable comparison with atmospheric measurements with a subset of cells in the SEI; the concept of distributing emissions based on statistical considerations is expected to lower emission estimates from grid cells where cattle actually are found but increase emissions from grid cells where in reality no cattle are found, an artefact that we tried to overcome via our CHAI estimate.

A differentiation is needed between the validation (1) of livestock $\mathrm{CH}_{4}$ emission estimates and (2) of emission factors used for inventory estimates. Most studies address the validation of EFs via direct measurements at the individual animal level (Ulyatt et al., 2002; Zeitz et al., 2012). Our study, on the contrary, focused (a) on the validation of livestock $\mathrm{CH}_{4}$ emission estimates, by examining the appropriateness of the methodology used in the inventory, and (b) on evaluating whether the estimates are consistent with direct atmospheric measurements (Lowry et al., 2001; Lassey, 2007). Using actual livestock data (CHAI), the inventory estimates were of the same order of magnitude as atmospheric measurements. Therefore, statistical assessments and inventories are indeed able to reliably represent $\mathrm{CH}_{4}$ emissions from livestock, even though the estimates are based on given default values. Beside that, our study showed that the methodology used in the inventory estimates is a suitable tool for resolving current livestock $\mathrm{CH}_{4}$ emissions at farm scale and can - at least for the period of data collection - be applied at larger scales as well, e.g. at regional to national scales.

\section{Conclusions}

Direct inventory estimates based on actual local livestock numbers (CHAI: $1.29 \pm 0.47$ and $1.74 \pm 0.63 \mu \mathrm{g} \mathrm{CH}_{4} \mathrm{~m}^{-2} \mathrm{~s}^{-1}$ in 2011 and 2012 respectively) and mean NBL budget fluxes (ranging between $1.22 \pm 0.1$ and $2.05 \pm 0.45 \mu \mathrm{g} \mathrm{CH}_{4} \mathrm{~m}^{-2} \mathrm{~s}^{-1}$ ) agreed well, after appropriate selection of available sounding data was made (Sect. 2.3). Thus, estimates based on actual livestock data and default emission factors showed that inventory assessments give plausible results, confirming the quality of the methodology used by such inventories.

Nevertheless, further improvements of the NBL budget flux approach are possible and are necessary for future studies. The sensitivity of the NBL approach to uncertain determinations of $z_{i}$ is one limiting factor, and the completely unrealistic fluxes that can result during nonstationary conditions - which were quite frequent during our 2011 field campaign - are another limitation. $\mathrm{CH}_{4}$ accumulations were generally greatest near the surface below the starting height of the tethered balloon system, and hence the combination with a tower profile covering the lowest heights above the surface (i.e. $0-10 \mathrm{~m}$ ) was an essential component in our NBL budget flux calculations. 
The multi-layer structure of the nocturnal atmosphere, with a typical inversion at around $50 \mathrm{~m}$ a.g.l. and opposing wind directions above and below, posed the greatest challenge for the NBL budget flux estimates. Hence, it is recommended to rather use the conventional approach with tethered balloon soundings effectuated at constant ascent and descent rates instead than the approach we used in summer 2012 with prolonged measurements at fixed heights across the relevant lower part of the NBL. Although this latter approach allowed for a much better assessment of the $\Delta \bar{c} / \Delta t=0 \mathrm{ppm} \mathrm{s}^{-1}$ criterion to estimate $z_{i}$ in the NBL budget flux calculations, this comes at the cost of losing a clear visual control over $z_{i}$ and potential additional shallower layers below $z_{i}$, which may remain undetected if no continuously measured temperature and relative humidity profiles are available.

In summary, the validation of inventory estimates via the NBL budget flux approach (with appropriate data selection) can be applied at different spatial scales, i.e. from a single farm to larger scales. Within the experimental uncertainty bounds, our study also raises confidence that the Swiss national inventory report reliably represents national livestock $\mathrm{CH}_{4}$ emissions.

Acknowledgements. Funding for this project was provided by the Swiss National Science Foundation grants no. 2.77771.10 and CRSII2_136273. We thank Peter Plüss and Thomas Baur for technical support, and Hans-Rudolf Wettstein and his team for their great efforts and support during the measurement campaigns at the ETH research station Chamau. Many thanks to Rebecca Hiller, Zürich, and Mathias Rotach, Innsbruck, for fruitful discussions and valuable comments. The spatially explicit inventory of Meteotest, Bern, was developed within the MAIOLICA project of the ETH Competence Center Environment and Sustainability (CCES).

Edited by: A. B. Guenther

\section{References}

ART: Agricultural $\mathrm{CH}_{4}$ and $\mathrm{N}_{2} \mathrm{O}$ emissions in Switzerland, Agroscope Reckenholz Tänikon Research Station (ART), QA/QC Internal Report, Zurich, Switzerland, 61 pp., 2012.

Baldocchi, D., Detto, M., Sonnentag, O., Verfaillie, J., The, Y., Silver, W., and Kelly, N.: The challenges of measuring methane fluxes and concentrations over a peatland pasture, Agr. Forest Meteorol., 153, 177-187, doi:10.1016/j.agrformet.2011.04.013, 2012.

Bamberger, I., Stieger, J., Buchmann, N., and Eugster, W.: Spatial variability of methane: Attributing atmospheric concentrations to emissions, Environ. Pollut., 190, 65-74, doi:10.1016/j.envpol.2014.03.028, 2014.

Beswick, K., Simpson, T., Fowler, D., Choularton, T., Gallagher, M., Hargreaves, K., Sutton, M., and Kaye, A.: Methane emissions on large scales, Atmos. Environ., 32, 3283-3291, doi:10.1016/S1352-2310(98)00080-6, 1998.
Choularton, T., Gallagher, M., Bower, K., Fowler, D., Zahniser, M., Kaye, A., Monteith, J., and Harding, R.: Trace gas flux measurements at the landscape scale using boundary-layer budgets, Philos. T. R. Soc. A, 351, 357-369, doi:10.1098/rsta.1995.0039, 1995.

Christie, K., Gourley, C., Rawnsley, R., Eckard, R., and Awty, I.: Whole-farm systems analysis of Australian dairy farm greenhouse gas emissions, Anim. Prod. Sci., 62, 998-1011, doi:10.1071/AN12061, 2012.

Cleugh, H., Raupach, M., Briggs, P., and Coppin, P.: Regional-scale heat and water vapour fluxes in an agricultural landscape: an evaluation of CBL budget methods at OASIS, Bound.-Lay. Meteorol., 110, 99-137, doi:10.1023/A:1026096711297, 2004.

Deighton, M., Williams, R., Hannah, M., Eckard, R., Boland, T., Wales, W., and Moate, P.: A modified sulphur hexafluoride tracer technique enables accurate determination of enteric methane emissions from ruminants, Anim. Feed Sci. Tech., 197, 47-63, doi:10.1016/j.anifeedsci.2014.08.003, 2014.

Dengel, S., Levy, P., Grace, J., Jones, S., and Skiba, U.: Methane emissions from sheep pasture, measured with an open-path eddy covariance system, Glob. Change Biol., 17, 3524-3533, doi:10.1111/j.1365-2486.2011.02466.x, 2011.

Denmead, O., Raupach, M., Dunin, F., Cleugh, H., and Leuning, R.: Boundary layer budgets for regional estimates of scalar fluxes, Glob. Change Biol., 2, 255-264, doi:10.1111/j.13652486.1996.tb00077.x, 1996.

Denmead, O. T., Leuning, R., Griffith, D. W. T., Jamie, I. M., Esler, M. B., Harper, L. A., and Freney, J. R.: Verifying inventory predictions of animal methane emissions with meteorological measurements, Bound.-Layer Meteorol., 96, 187-209, 2000.

Detto, M., Baldocchi, D., and Katul, G.: Scaling properties of biologically active scalar concentration fluctuations in the atmospheric surface layer over a managed peatland, Bound.-Lay. Meteorol., 136, 407-430, doi:10.1007/s10546-010-9514-z, 2010.

Dlugokencky, E., Nisbet, E., Fisher, R., and Lowry, D.: Global atmospheric methane: budget, changes and dangers, Philos. T. R. Soc. A, 369, 2058-2072, doi:10.1098/rsta.2010.0341, 2011.

Dorninger, M., Whiteman, C., Bica, B., Eisenbach, S., Pospichal, B., and Steinacker, R.: Meteorological events affecting cold-air pools in a small basin, J. Appl. Meteorol. Clim., 50, 2223-2234, doi:10.1175/2011JAMC2681.1, 2011.

Eggleston, H. S., Buendia, L., Miwa, K., Ngara, T., Tanabe, K. (Eds.): IPCC Guidelines for National Greenhouse Gas Inventories, Prepared by the National Greenhouse Gas Inventories Programme, Institute for Global Environmental Strategies, Hayama, Kanagawa, Japan, 2006.

Eugster, W. and Siegrist, F. C.: The influence of nocturnal $\mathrm{CO}_{2}$ advection on $\mathrm{CO}_{2}$ flux measurements, Basic Appl. Ecol., 1, 177188, 2000.

FOEN: Switzerland's Greenhouse Gas Inventory 1990-2013: National Inventory Report 2015, Submission of 15 April 2015 under the United Nations Framework Convention on Climate Change and under the Kyoto Protocol, Federal Office for the Environment FOEN, Bern, Switzerland, 596 pp., 2015.

Fowler, D., Hargreaves, K. J., Choularton, T. W., Gallagher, M. W., Simpson, T., and Kaye, A.: Measurements of regional $\mathrm{CH}_{4}$ emissions in the UK using boundary layer budget methods, Energy Conversion and Management, 37, 769-775, 1996. 
FSO: CORINE Land cover map, Swiss Federal Statistical Office (FSO), Neuchatel, Switzerland, 1998.

FSO: Land use statistics (Arealstatisik) 1992/97, NOAS92, Swiss Federal Statistical Office (FSO), Neuchatel, Switzerland, 2007.

FSO: Data extract of census of agricultural entreprises 2007, Swiss Federal Statistical Office (FSO), Neuchatel, Switzerland, 2009.

FSO: Land use statistics (Arealstatistik) 2004/09, NOLU04/20120821, Swiss Federal Statistical Office (FSO), Neuchatel, Switzerland, 2012.

Gilgen, A. and Buchmann, N.: Response of temperate grasslands at different altitudes to simulated summer drought differed but scaled with annual precipitation, Biogeosciences, 6, 2525-2539, doi:10.5194/bg-6-2525-2009, 2009.

Griffith, D. W. T., Bryant, G. R., Hsu, D., and Reisinger, A. R.: Methane emissions from free-ranging cattle: Comparison of tracer and integrated horizontal flux techniques, J. Environ. Qual., 37, 582-591, doi:10.2134/jeq2006.0426, 2008.

Grobler, S., Scholtz, M. M., van Rooyen, H., Mpayipheli, M., and Neser, F. W. C.: Methane production in different breeds, grazing different pastures or fed a total mixed ration, as measured by a Laser Methane Detector, S. Afr. J. Anim. Sci., 44, S12-S16, 2014.

Harper, L., Denmead, O., and Flesch, T.: Micrometeorological techniques for measurement of enteric greenhouse gas emissions, Anim. Feed Sci. Tech., 166, 227-239, doi:10.1016/j.anifeedsci.2011.04.013, 2011.

Hartmann, A., Buchmann, N., and Niklaus, P.: A study of soil methane sink regulation in two grasslands exposed to drought and $\mathrm{N}$ fertilization, Plant Soil, 342, 265-275, doi:10.1007/s11104-010-0690-x, 2011.

Heimann, M.: Atmospheric science: Enigma of the recent methane budget, Nature, 476, 157-158, doi:10.1038/476157a, 2011.

Hiller, R. V., D.Bretscher, Sontro, T. D., Diem, T., Eugster, W., Henneberger, R., Hobi, S., Hodson, E., Imer, D., Kreuzer, M., Künzle, T., Merbold, L., Niklaus, P. A., Rihm, B., Schellenberger, A., Schroth, M. H., Schubert, C. J., Siegrist, H., Stieger, J., Buchmann, N., and Brunner, D.: Anthropogenic and natural methane fluxes in Switzerland synthesized within a spatially explicit inventory, Biogeosciences, 11, 1941-1960, doi:10.5194/bg-111941-2014, 2014a.

Hiller, R. V., Neininger, B., Brunner, D., Gerbig, C., Bretscher, D., Künzle, T., Buchmann, N., and Eugster, W.: Aircraft-based $\mathrm{CH}_{4}$ flux estimates for validation of emissions from an agriculturally dominated area in Switzerland, J. Geophys. Res., 119, 1-14, doi:10.1002/2013JD020918, 2014b.

Holden, J., Derbyshire, S., and Belcher, S.: Tethered balloon observations of the nocturnal stable boundary layer in a valley, Bound.-Lay. Meteorol., 97, 1-24, doi:10.1023/A:1002628924673, 2000.

Hsu, Y., VanCuren, T., Park, S., Jakober, C., Herner, J., FitzGibbon, M., Blake, D., and Parrish, D.: Methane emissions inventory verification in southern California, Atmos. Environ., 44, 17, doi:10.1016/j.atmosenv.2009.10.002, 2010.

Imer, D., Merbold, L., Eugster, W., and Buchmann, N.: Temporal and spatial variations of soil $\mathrm{CO}_{2}, \mathrm{CH}_{4}$ and $\mathrm{N}_{2} \mathrm{O}$ fluxes at three differently managed grasslands, Biogeosciences, 10, 5931-5945, doi:10.5194/bg-10-5931-2013, 2013.

Johnson, K., Huyler, M., Westberg, H., Lamb, B., and Zimmerman, P.: Measurement of methane emissions from ruminant live- stock using a SF6 tracer technique, Environ. Sci. Technol., 28, 359-362, 1994.

Judd, M. J., Keillier, F. M., Ulyatt, M. J., Lassey, K. R., Tate, K. R., Shelton, I. D., Harvey, M. J.,and Walker, C. F.: Net methane emission from grazing sheep, Global Change Biology, 5, 647657, 1999.

Kuck, L., Smith Jr, T., Balsley, B., Helmig, D., Conway, T., Tans, P., Davis, K., Jensen, M., Bognar, J., Arrieta, R., and others: Measurements of landscape-scale fluxes of carbon dioxide in the Peruvian Amazon by vertical profiling through the atmospheric boundary layer, J. Geophys. Res., 105, 22137-22146, doi:10.1029/2000JD900105, 2000.

Lassey, K.: Livestock methane emission: from the individual grazing animal through national inventories to the global methane cycle, Agr. Forest Meteorol., 142, 120-132, doi:10.1016/j.agrformet.2006.03.028, 2007.

Lassey, K.: Livestock methane emission and its perspective in the global methane cycle, Anim. Prod. Sci., 48, 114-118, doi:10.1071/EA07220, 2008.

Lassey, K. R., Gimson, N. R., Wratt, D. S., Brailsford, G. W., and Bromley, A. M.: Verifying agricultural emissions of methane: air sampling from aircraft and mesoscale modelling, in: Non- $\mathrm{CO}_{2}$ greenhouse gases: Scientific understanding, control and implementation, edited by: Van Ham, J., Baede, A. P. M., Meyer, L. A., and Ybema, R., 107-114, doi:10.1007/978-94-015-9343-4, 2000.

Laubach, J. and Kelliher, F. M.: Measuring methane emission rates of a dairy cow herd by two micrometeorological techniques, Agr. Forest Meteorol., 125, 279-303, doi:10.1016/j.agrformet.2004.04.003, 2004

Laubach, J. and Kelliher, F. M.: Methane emissions from dairy cows: Comparing open-path laser measurements to profile based techniques, Agr. Forest Meteorol., 135, 340-345, 2005.

Laubach, J. and Kelliher, F. M.: Measuring methane emission rates of a diary cow herd (II): results from a backward-Lagrangian stochastic model, Agr. Forest Meteorol., 129, 137-150, 2005.

Laubach, J., Kelliher, F. M., Knight, T. W., Clark, H., Molano, G., and Cavanagh, A.: Methane emissions from beef cattle - a comparison of paddock- and animal-scale measurements, Animal Production Science, 48, 132-137, 2008.

Levin, I., Glatzel-Mattheier, H., Marik, T., Cuntz, M., and Schmidt, M.: Verification of German methane emission inventories and their recent changes based on atmospheric observations, J. Geophys. Res., 104, 3447-3456, doi:10.1029/1998JD100064, 1999.

Leytem, A. B., Dungan, R. S., Bjorneberg, D. L., and Koehn, A. C.: Emissions of ammonia, methane, carbon dioxide, and nitrous oxide from dairy cattle housing and manure management systems, J. Environ. Qual., 40, 1383-1394, doi:10.2134/jeq2009.0515, 2011.

Lowry, D., Holmes, C., Rata, N., O’Brian, P., and Nisbet, E.: London methane emissions: Use of diurnal changes in concentration and $\delta^{13} \mathrm{C}$ to identify urban sources and verify inventories, J. Geophys. Res., 106, 7427-7448, doi:10.1029/2000JD900601, 2001.

Mahrt, L. and Vickers, D.: Contrasting vertical structures of nocturnal boundary layers, Bound.-Lay. Meteorol., 105, 351-363, doi:10.1023/A:1019964720989, 2002.

Mathieu, N., Strachan, I., Leclerc, M., Karipot, A., and Pattey, E.: Role of low-level jets and boundary-layer properties on 
the NBL budget technique, Agr. Forest Meteorol., 135, 35-43, doi:10.1016/j.agrformet.2005.10.001, 2005.

McGinn, S. M. and Beauchemin, K. A.: Dairy farm methane emissions using a dispersion model, J. Environ. Qual., 41, 73-79, doi:10.2134/jeq2011.0266, 2012.

McGinn, S. M., Flesch, T. K., Harper, L. A., and Beuchemin, K. A.: An approach for measuring methane emissions from whole farms, J. Environ. Qual., 35, 14-20, doi:10.2134/jeq2005.0250, 2006.

McGinn, S. M., Turner, D., Tomkins, N., Charmley, E., BishopHurley, G., and Chen, D.: Methane emissions from grazing cattle using point-source dispersion, J. Environ. Qual., 40, 22-27, doi:10.2134/jeq2010.0239, 2011.

Merbold, L., Eugster, W., Stieger, J., Zahniser, M., Nelson, D., and Buchmann, N.: Greenhouse gas budget $\left(\mathrm{CO}_{2}, \mathrm{CH}_{4}\right.$ and $\left.\mathrm{N}_{2} \mathrm{O}\right)$ of intensively managed grassland following restoration, Glob. Change Biol., 20, 1913-1928, doi:10.1111/gcb.12518, 2014.

Messerli, P.: Die Ballonsondierungen in Hagnau vom 18. bis 20. Mai 1992, Seminararbeit, Institute of Geography, University of Bern, Bern, Switzerland, 71 pp., 1992.

Nisbet, E. and Weiss, R.: Top-down versus bottom-up, Science, 328, 1241-1243, doi:10.1126/science.1189936, 2010.

Parker, M. and Raman, S.: A case study of the nocturnal boundary layer over a complex terrain, Bound.-Lay. Meteorol., 66, 303324, doi:10.1007/BF00705480, 1993.

Pattey, E., Strachan, I., Desjardins, R., Edwards, G., Dow, D., and MacPherson, J.: Application of a tunable diode laser to the measurement of $\mathrm{CH}_{4}$ and $\mathrm{N}_{2} \mathrm{O}$ fluxes from field to landscape scale using several micrometeorological techniques, Agr. Forest Meteorol., 136, 222-236, doi:10.1016/j.agrformet.2004.12.009, 2006.

Pendall, E., Schwendenmann, L., Rahn, T., Millers, J., Tans, P., and White, J.: Land use and season affect fluxes of $\mathrm{CO}_{2}, \mathrm{CH}_{4}, \mathrm{CO}$, $\mathrm{N}_{2} \mathrm{O}, \mathrm{H}_{2}$ and isotopic source signatures in Panama: evidence from nocturnal boundary layer profiles, Glob. Change Biol., 16, 2721-2736, doi:10.1111/j.1365-2486.2010.02199.x, 2010.

Penman, J., Kruger, D., Galbally, I., Hiraishi, T., Nyenzi, B., Emmanual, S., Buendia, L., Hoppaus, R., Martinsen, T., Mejer, J., Miwa, K., and Tanabe, K. (Eds.): Good practice guidance and uncertainty management in national greenhouse gas inventories, IPCC National Greenhouse Cost Inventories programme, Technical Support Unit, Institute for Global Environmental Strategies, Hayama, Kanagawa, Japan, 2000.

Pinto, J., Parsons, D., Brown, W., Cohn, S., Chamberlain, N., and Morley, B.: Coevolution of down-valley flow and the nocturnal boundary layer in complex terrain, J. Appl. Meteorol. Clim., 45, 1429-1449, doi:10.1175/JAM2412.1, 2006.

R Core Team: R: A Language and Environment for Statistical Computing, R Foundation for Statistical Computing, Vienna, Austria, available at: http://www.R-project.org/, 2014.

Raupach, M., Denmead, O., and Dunin, F.: Challenges in linking atmospheric $\mathrm{CO}_{2}$ concentrations to fluxes at local and regional scales, Aust. J. Bot., 40, 697-716, doi:10.1071/BT9920697, 1992.

Saggar, S., Bolan, N., Bhandral, R., Hedley, C., and Luo, J.: A review of emission of methane, ammonia, and nitrous oxide from animal excreta deposition and farm effluent application in grazed pastures, New Zeal. J. Agr. Res., 47, 513-544, 2004.

Siegrist, F. C.: Determination of energy and trace gas fluxes on a regional scale: Combination of local surface flux measurements and vertical flux profiles throughout the atmospheric boundary layer in complex terrain (Swiss Seeland region), $\mathrm{PhD}$ thesis, University of Bern, Institute of Geography, University of Bern, Geographical Institute, Hallerstrasse 12, 3012 Bern, Switzerland, vol. G67 of Geographica Bernensia, 113 pp., 2001.

Soliva, C.: Report to the attention of IPCC about the data set and calculation method used to estimate methane formation from enteric fermentation of agricultural livestock population and manure management in Swiss agriculture, Institute of Animal Science, ETH Zurich, Switzerland. On behalf of the Federal Office for the Environment (FOEN), Bern, Switzerland, 14 pp., 2006.

Staerfl, S., Zeitz, J., Kreuzer, M., and Soliva, C.: Methane conversion rate of bulls fattened on grass or maize silage as compared with the IPCC default values, and the long-term methane mitigation efficiency of adding acacia tannin, garlic, maca and lupine, Agric. Ecosyst. Environ., 148, 111-120, doi:10.1016/j.agee.2011.11.003, 2012.

Sun, J., Burns, S., Delany, A., Oncley, S., Turnipseed, A., Stephens, B., Lenschow, D., LeMone, M., Monson, R., and Anderson, D.: $\mathrm{CO}_{2}$ transport over complex terrain, Agr. Forest Meteorol., 145, 1-21, doi:10.1016/j.agrformet.2007.02.007, 2007.

Suter, F.: Greenhouse gases from managed ecosystems: a farm scale perspective. Insights from a consolidated greenhouse gas budgets of a typical Swiss three-stage grassland farming system, ETH Master thesis, ETH Zurich, Zurich, Switzerland, 69 pp., 2011.

Ulyatt, M., Lassey, K., Shelton, I., and Walker, C.: Seasonal variation in methane emission from dairy cows and breeding ewes grazing ryegrass/white clover pasture in New Zealand, New Zeal. J. Agr. Res., 45, 217-226, 2002.

Utiger, M.: Ballonsondierung Merenschwand vom 16.-18.06.1992, Seminararbeit, Insitute of Geography, University of Bern, Bern, 98 pp., 1992.

van Ham, J., Baede, A. P. M., Meyer, L. A., and Ybema, R. (Eds.): Non- $\mathrm{CO}_{2}$ greenhouse gases: Scientific understanding, control and implementation, Kluwer Academic, Dordrecht, the Netherlands, 604 pp., 2000.

Wang, F. L., Bettany, J. R., and Huang, P. M.: Methane uptake by cultivated Canadian prairie and forest soils, Geoderma, 88, 3953, doi:10.1016/S0016-7061(98)00076-7, 1999.

Wang, J., Cardenas, L., Misselbrook, T., and Gilhespy, S.: Development and application of a detailed inventory framework for estimating nitrous oxide and methane emissions from agriculture, Atmos. Environ., 45, 1454-1463, doi:10.1016/j.atmosenv.2010.12.014, 2011.

Wang, S., Ackermann, R., and Stutz, J.: Vertical profiles of $\mathrm{O}_{3}$ and $\mathrm{NO}_{x}$ chemistry in the polluted nocturnal boundary layer in Phoenix, AZ: I. Field observations by long-path DOAS, Atmos. Chem. Phys., 6, 2671-2693, doi:10.5194/acp-6-2671-2006, 2006.

Wratt, D. S., Gimson, N. R., Brailsford, G. W., Lassey, K. R., Bromley, A. M., and Bell, M. J.: Estimating regional methane emissions from agriculture using aircraft measurements of concentration profiles, Atmos. Environ., 35, 497-508, doi:10.1016/S13522310(00)00336-8, 2001.

Zeeman, M., Werner, R., Eugster, W., Siegwolf, R., Wehrle, G., Mohn, J., and Buchmann, N.: Optimization of automated gas sample collection and isotope ratio mass spectrometric analysis of $\delta^{13} \mathrm{C}$ of $\mathrm{CO}_{2}$ in air, Rapid Commun. Mass Sp., 22, 3883-3892, doi:10.1002/rcm.3772, 2008. 
Zeeman, M., Hiller, R., Gilgen, A., Michna, P., Plüss, P., Buchmann, N., and Eugster, W.: Management and climate impacts on net $\mathrm{CO}_{2}$ fluxes and carbon budgets of three grasslands along an elevational gradient in Switzerland, Agr. Forest Meteorol., 150, 519-530, doi:10.1016/j.agrformet.2010.01.011, 2010.

Zeitz, J., Solvia, C., and Kreuzer, M.: Swiss diet types for cattle: how accurately are they reflected by the Intergovernmental Panel on Climate Change default values?, J. Integr. Environ. Sci., 9, 199-216, doi:10.1080/1943815X.2012.709253, 2012.
Zinchenko, A., Paramonova, N., Privalov, V., and Reshetnikov, A.: Estimation of methane emissions in the St. Petersburg, Russia, region: an atmospheric nocturnal boundary layer budget approach, J. Geophys. Res., 107, 1451-1476, doi:10.1029/2001JD001369, 2002. 